\title{
Analysis of effects of extension teaching methods on farmers' level of cassava and maize production in Ogun State, Nigeria
}

\author{
S. O. APANTAKU, O. OLUFADE, K. ADEBAYO \& A. OYEKANMI
}

(S. O. A. \& K. A.: Department of Agricultural Extension and Rural Development, University of Agriculture, PMB 2240, Abeokuta, Nigeria (UNAAB); O. O.: Ogun State Agricultural Development Programme, Abeokuta, Nigeria; A. O.: Department of Plant Physiology and Crop Production, $U N A A B)$

\begin{abstract}
This study analyzed the effects of extension teaching methods used by Ogun State (Nigeria) Agricultural Development Programme's extension agents on farmers' level of production in maize and cassava. The sample included 210 randomly selected farmers, comprising adopters and non-adopters of introduced agricultural technologies. The result indicated a high level of awareness and low level of adoption of some essential components of the recommended technologies such as fertilizer and herbicide application. Adopting the technologies is affected by high cost and non-availability of inputs as and when needed. The study also showed that the type of extension teaching methods used by extension agents or which farmers had access to have varying effects on their levels of production. The use of a combination of individual, group and mass methods of extension teaching had the best association and effect on production output. The study recommended that non-adopters (and lowadopters) should be identified and extension efforts concentrated toward them, essential inputs should be provided at the right time and at affordable prices, organic manure (e.g. compost) should be used as a substitute for fertilizer by farmers where it is unavailable, and that the use of a combination of extension teaching methods and media by extension agents should be encouraged.
\end{abstract}

Original scientific paper. Received 29 Mar 05; revised 16 Aug 07.

\section{RÉSUMÉ}

Apantaku, S. O., Olufade, O., Adebayo, K. \& Oyekanmi, A.: Analyse d' effets de méthodes d'enseignement de vulgarisation sur le niveau de production de manioc et de maïs par les agriculteurs dans l' Etat Ogun, Nigéria. Il est généralement conçu que le moyen le plus efficace d' améliorer l' éfficience agricole est d' augmenter la production agricole est d' éduquer les agriculteurs. Cette étude a fait une analyse d' effets de méthodes d'enseignement de vulgarisation employées par les agents de vulgarisation du programme de développement d' agriculture de 1' Etat Ogun (Nigéria) sur le niveau de production de maïs et de manioc par les agriculteurs. L' échantillon a inclus 210 agriculteurs prélevés au hasard, comprenant les adoptants et les non-adoptants de technologies d'agriculture introduites. Le résultat a indiqué un haut niveau de sensibilisation et un faible niveau d' adoption de quelques éléments essentiels de technologies recommandées tels que l'application d' engrais et de herbicide. L' adoption des technologies est affectée par le coût élevé et la non-disponibilité d' intrants lorsqu' ils sont exigés. L' étude révélait également que le type de méthode d' enseignement de vulgarisation employé par les agents de vulgarisation ou auquel les agriculteurs ont accès avait des effets variés sur leurs niveaux de production. L' emploi d' une combinaison de méthodes d' individu, de groupe et de masse d' enseignement de vulgarisation ont la meilleure association et effet sur la production. L' étude a recommandé que les non-adoptants (et les faibles adoptants) devraient être identifié et les efforts de vulgarisation devraient être concentré sur eux, les intrants essentiels devraient être rendu disponible à l' heure exacte et aux prix abordables, l' emploi d' engrais organique (par ex. le compost) comme un remplaçant d' engrais chimique par les agriculteurs dans les zones où il n'est pas disponible, et l'emploi d' une combinaison de méthodes d' enseignement de vulgarisation et de médias par les agents de vulgarisation devraient être encouragé.

Ghana Jnl agric. Sci. 41, 103-111 


\section{Introduction}

Increased agricultural productivity depends primarily on accepting cultural and technological changes at rural farm level. Peasant farmers can achieve higher farm yields if they adopt improved farming techniques; but some new practices are sometimes complicated, making adoption difficult for non-literate farmers. To adopt and successfully use improved farming techniques, peasant farmers must understand them. This requires effective teaching by the agricultural extension service (agents) (Kelsey \& Hearne, 1995). Therefore, extension education provides practical learning opportunities for rural people to acquire the necessary knowledge and skills that would enable them choose wisely, act productively, and grow individually while contributing to national progress (van den Ban \& Hawkins, 1988). Different extension methods are used during this educational procedure. According to Farinde \& Jibowo (1996), the selection and use of any extension teaching method depends on characteristics of the method, type of audience to be reached by extension workers, and type of message (agricultural innovation) to be disseminated.

In Nigeria, the government agency responsible for extension service, including disseminating improved farming techniques to peasant farmers, is the Agricultural Development Programme (ADP). The ADP was introduced by the World Bank in 1975 to replace the traditional extension service. In Nigeria, the ADPs use the training and visit $(\mathrm{T} \& \mathrm{~V})$ system of extension in their operation, usually after conducting a formal participatory onfarm adaptive trial which is recommendationdomain specific.

The Ogun State Agricultural Development Programme (OGADEP), one of the first seven multi-state ADPs (MSADP-1) in Nigeria, was launched on 4th February 1986 against the backdrop of a deflated agricultural sector at the national level. At the state level, the dysfunctional extension service was caused by inadequate funding, insufficient functional facilities, under-trained and unmotivated field personnel who were too few to run any meaningful extension system (OGADEP, 1996). The objective of OGADEP was to effectively reach over 250,000 farm families in the state with improved agricultural techniques through the $\mathrm{T} \& \mathrm{~V}$ system of extension, thereby increasing agricultural productivity and income of smallholder farmers in the state (OGADEP, 1997). The OGADEP now enjoys funding assistance from the International Fund for Agricultural Development (IFAD), specifically toward the cassava multiplication and improvement programme.

The drastic fall recorded in cassava production, due to the combined effects of pests and diseases that ravaged most cassava fields in major producing areas between 1987 and 1996, led to government's direct intervention in the subsector by implementing IFAD-assisted Cassava Multiplication Project (CMP). The objective of the CMP was to multiply, promote and distribute improved varieties (TMS 30555 and TMS 30572) that produce higher yields (10-15 tons fresh tuber per hectare) and are resistant to pests and diseases (cassava mosaic and cassava bacteria blight) (OGADEP, 1995).

The CMP also engaged in disseminating improved technologies on maize production in the state, because most farmers intercrop cassava with maize. The socio-economic importance of maize, infestation of maize by diseases (downy mildew and maize streak), and low yield of local varieties led to improved cultivars being introduced. The FARZ-7, DMRSR-Y, DMRESR-W, DMRSR-W, TZESR-W, TZESR-Y, and TZSR-Y were the most promising improved cultivars in yield (2-3 tons dry grains per hectare) and in resistance to pests and diseases in the state.

In ensuring that farmers adopt the agricultural innovations, different extension methods are used by OGADEP to disseminate and educate farmers. It is thought that effective use of these methods must have an overall effect on farmers' level of production (Adefuye, 1996). However, it has been realized over a decade ago that the number of 
innovations being introduced to farmers are too many to be adopted effectively without problems (Adefuye, 1996). He stated further that there had been no appreciable increase in farmers' production output even where the innovations were adopted. Aboyade (1997) took a critical look at the problem and found out that farmers were neither adequately nor appropriately informed about innovations that were meant to be adopted by them to achieve improved agricultural productivity. Another fundamental problem with extension strategy was that some recommendations were irrelevant. The technological options offered by extension did not often fit into the farming system and the socioeconomic conditions under which the rural people were operating (FMANR, 1997).

It may be difficult to specifically pin down the cause(s) of the drastic fall in cassava and maize production (OGADEP, 1997) to some factor(s). However, against the background of assertions and query on the methods used in disseminating information and agricultural technologies (Adefuye, 1996; Aboyade, 1997), and the researchers' observations and experiences, this study was designed to examine the effects of OGADEP extension methods on farmers' level of production (output) in maize and cassava. Specifically, the study sought to:

1. identify and describe the socio-economic characteristics of farmers reached with the extension methods used by OGADEP;

2. determine the level of awareness and adoption of selected improved agricultural practices by farmers; and

3. investigate the effects (relationships) between the types of extension method used by OGADEP on (with) farmers' level of production (output) in cassava and maize.

\section{Theoretical framework}

This study is underpinned on the "Knowledge Gap Theory". Knowledge is expressed in articulated understandings, skills and judgements that are professional in character and distinguish more productive individuals from less productive ones (Carey, 1999). According to Adekanye (1988), individuals and groups within the agricultural knowledge and information system are unequal or heterogeneous in many of their socio-economic characteristics and, therefore, in their access to agricultural information as well as participation in the macro system of agricultural information flow. These inequalities have, therefore, segregated several components of each of the major systems in the macro system. Arising from this, Tichenor (1986) came up with the Knowledge Gap Theory.

This theory posits that in any system in which the distribution of resource is unequal, an educational programme that seeks to make information equally available to all members of the system will end up widening the gap or differences in knowledge between the "haves" and "have-nots". The import of this is that for greater effectiveness amongst the less competitive participants, the information system might have to be favourably tilted toward the "have-nots". While this advocacy is suitable, Adams (1992) observed that extension agencies in developing countries have chosen to adopt the "trickle down" approach in which they focus their attention on the more progressive farmers, with little benefit to the mass of conservative rural farmers. This, he contends, will continue to increase the gap and gulf between the progressive farmers and the rest. Similarly, van den Ban \& Hawkins (1988) suggested non-availability of innovations in remote villages and disseminating innovations in larger quantities (than a small farmer can use or afford) as reasons for poor farmers' slowness in adopting innovations.

To influence development-related knowledge and information process in rural communities, Huizinger, van Raalte \& Rolling (1982) proposed a target-category approach in which they stated that extension has to squarely face the issue of heterogeneity in the farming population. This implies a need for segmenting the population into 
target-categories to maximize homogeneity within target-categories and heterogeneity between them. The target-category approach calls for careful analysis of the farming population and classification of that population into homogeneous target-categories, careful study of individual target-categories to design appropriate technologies and targeted specific extension methods and delivery mechanism. Adedoyin \& Adesanoye (1996) suggested a multimedia approach for effective communication to rural people as well as understanding of the target audience, the needs and interests of the intended beneficiaries.

\section{Materials and methods}

For the study, two out of four operation zones of OGADEP randomly selected were Abeokuta and Ilaro. Two extension operation blocks were randomly selected from each zone (Oke-odan and Sawonjo in Ilaro zone, and Ilewo and Opeji in Abeokuta zone), making four blocks. Three extension cells were randomly selected from each block, giving a total of 12 extension cells (Ilase, Oke-odan, Agosasa, Ibese, Sawonjo, Iboro, Isaga, Ilewo, Ibara-orile, Obete, Ijo-agbe, and Alabata ). Twenty cassava and maize farmers were randomly selected from each of the 12 cells to give a total of 240 farmers; however, 210 were actually contacted. All the 12 extension agents covering the selected cells and the OGADEP information officer were interviewed. (Usually one extension agent for each extension cell).

Five improved technologies recommended and introduced by OGADEP were considered for the study. These were use of improved variety of seeds, plant spacing, fertilizer application, timely weeding, and use of herbicides. Data were collected between June and December 2004, using validated structured interview schedule to elicit information from the farmers, while the extension agents and OGADEP information officer responded to questionnaires. The interview and administration of the questionnaire were personally handled by the researchers. The interview schedule and questionnaire were adjudged to have content and face validity by a panel of three professors in agricultural extension. The instruments were also pre-tested using the test-retest method. Reliability coefficient of 0.93 and 0.80 were recorded for the interview schedule and questionnaire, respectively. Relative frequency and chi-square tests were used to analyze the data.

\section{Results and discussion}

Characteristics of farmers

Table 1 shows that most (71.9\%) farmers were male and 90 per cent were married. Most (72.4\%) farmers belonged to the age range of 31 to 50. A predominance of male middle-aged people is inferred, who are expected to be very active and desirous of information that can improve farm productivity in the study area. Over half (56.2\%) of the farmers were not formally educated, while the rest had between primary, secondary and tertiary education. About 24.3 per cent of the farmers had between 6 and 10 years of farming experience, while the rest had between 11 and 31 years and above. Over 80 per cent had farm holdings below 2.0 ha. These findings are similar to those of Adebayo \& Ajayis (2001) and Apantaku et al. (2000) on the socio-economic and demographic characteristics (gender, marital status, age and level of education) of farmers in Ogun State.

\section{Extension methods used by OGADEP}

Data collected from the farmers and OGADEP's extension agents showed that the extension teaching methods used to reach farmers were individual contact, demonstrations, field days, group discussions, workshops, technical bulletins, and visual aids. All these were in addition to the use of radio and television programmes that were broadcast twice and once weekly, respectively, on the local radio and TV stations (Table 2). 
TABLE 1

Distribution of Respondents According to Some Socio-economic Characteristics $(n=210)$

\begin{tabular}{|c|c|c|c|c|}
\hline Characteristic & Frequency & $\%$ & Mean & Mode \\
\hline \multicolumn{5}{|l|}{ Gender } \\
\hline Male & 151 & 71.9 & & \multirow[t]{2}{*}{ Male } \\
\hline Female & 59 & 28.1 & & \\
\hline \multicolumn{4}{|l|}{ Marital Status } & \multirow[t]{4}{*}{ Married } \\
\hline Single & 13 & 6.2 & & \\
\hline Married & 189 & 90.0 & & \\
\hline Widowed & 8 & 3.8 & & \\
\hline \multicolumn{5}{|l|}{ Age (years) } \\
\hline Under 20 & 0 & 0 & \multirow{5}{*}{41.9} & \multirow{5}{*}{$31-40$ yrs } \\
\hline $21-30$ & 18 & 8.6 & & \\
\hline $31-40$ & 80 & 38.1 & & \\
\hline $41-50$ & 72 & 34.3 & & \\
\hline Above 50 & 40 & 19.0 & & \\
\hline \multicolumn{5}{|l|}{ Level of Education } \\
\hline No formal education & 118 & 56.2 & & \multirow{4}{*}{$\begin{array}{l}\text { No formal } \\
\text { education }\end{array}$} \\
\hline Primary/Standard school & 55 & 26.2 & & \\
\hline Secondary/Modern school & 22 & 10.5 & & \\
\hline Post secondary school & 15 & 7.1 & & \\
\hline \multicolumn{5}{|l|}{ Farming Experience } \\
\hline $1-5 \mathrm{yrs}$ & 20 & 9.5 & \multirow{7}{*}{16.14} & \multirow{7}{*}{$6-10 \mathrm{yrs}$} \\
\hline $6-10 \mathrm{yrs}$ & 51 & 24.3 & & \\
\hline $11-15$ yrs & 39 & 18.6 & & \\
\hline $16-20 \mathrm{yrs}$ & 39 & 18.6 & & \\
\hline $21-25 \mathrm{yrs}$ & 23 & 11.0 & & \\
\hline $26-30 \mathrm{yrs}$ & 14 & 6.7 & & \\
\hline 31 and above & 24 & 11.4 & & \\
\hline \multicolumn{5}{|l|}{ Farm Size } \\
\hline 1 ha and below & 102 & 48.6 & \multirow{5}{*}{$1.4 \mathrm{ha}$} & \multirow{5}{*}{1 ha and below } \\
\hline $1.1-2$ ha & 75 & 35.7 & & \\
\hline $2.1-3$ ha & 27 & 12.9 & & \\
\hline $3.1-4$ ha & 4 & 1.9 & & \\
\hline Above 4 ha & 2 & 0.95 & & \\
\hline
\end{tabular}

Farmers' access to extension methods

Table 2 shows that most of the high-adopters had access to radio (98.7\%), group discussion $(95.3 \%)$ and individual contact $(91.3 \%)$, while lowadopters had access to radio $(71.7 \%)$, field days $(36.7 \%)$ and group discussion $(31 \%)$. (Note that "access" here means extension teaching methods and media with which farmers are taught, or exposure to extension teaching methods and media.) These results indicate that radio is the most popular source of agricultural information used by farmers in the study area. This finding corroborates those of Adedoyin \& Adesanoye (1996) and Ewuola (1986) that over 70 per cent farmers in their studies used radio as their major source of agricultural information. Table 2 also shows that high-adopters and low-adopters have less access to bulletins and agricultural shows. 
TABLE 2

Distribution of Farmers According to their Access to Extension Methods Used by OGADEP $(n=210)$

\begin{tabular}{|c|c|c|c|c|c|c|}
\hline \multirow[b]{2}{*}{ Extension method } & \multicolumn{3}{|c|}{ High-adopters $\quad(n=150)$} & \multicolumn{2}{|c|}{ Low-adopters } & $(n=60)$ \\
\hline & Frequency & $\%$ & Rank & Frequency & $\%$ & Rank \\
\hline Individual contact & 137 & 91.3 & 3 & 12 & 20.0 & 4 \\
\hline \multicolumn{7}{|l|}{ Group methods } \\
\hline Group discussion & 143 & 95.3 & 2 & 19 & 31.7 & 3 \\
\hline Demonstration & 69 & 46.0 & 5 & 3 & 5.0 & 6 \\
\hline Field days & 81 & 54.0 & 4 & 22 & 36.7 & 2 \\
\hline Agricultural show & 50 & 33.3 & 7 & 7 & 11.7 & 5 \\
\hline \multicolumn{7}{|l|}{ Mass method } \\
\hline Bulletins/Posters & 59 & 39.3 & 6 & 2 & 3.3 & 7 \\
\hline Radio & 148 & 98.7 & 1 & 43 & 71.7 & 1 \\
\hline TV & 27 & 18.0 & 8 & 2 & 3.3 & 7 \\
\hline
\end{tabular}

The low access to bulletins may be due to low level of education among the farmers, or probably because extension agents seldom use bulletins and agricultural shows to disseminate information and recommended technologies and practices to farmers. More $(91.3 \%)$ high-adopters have access to individual contact while only 20 per cent of low-adopters have access to and are taught by (exposed to) individual extension contact.

Awareness and adoption of improved practices

Almost all respondents were aware of all the improved technologies (Table 3). Furthermore, over 50 per cent of the farmers adopted improved variety of seeds, plant spacing, and timely weeding. Adoption of fertilizer application was 45 per cent, while adoption level for herbicide was 10 per cent. The high level of awareness could probably be attributed to the effectiveness of the extension methods used by OGADEP. The low level of fertilizer and herbicide adoption may be serious impediments that may impair maize and cassava from attaining the avowed potentials. Some reasons given by farmers for not adopting some innovations were high cost of inputs,
TABLE 3

Farmers' Awareness and Adoption of Improved Practices ( $n=210)$

\begin{tabular}{lcr}
\hline Recommended practice & $\begin{array}{c}\text { Total } \\
\text { awareness } f(\%)\end{array}$ & $\begin{array}{c}\text { Total adoption } \\
f(\%)\end{array}$ \\
\hline Improved variety of seeds & $210(100 \%)$ & $141(67 \%)$ \\
Plant spacing & $189(90 \%)$ & $117(56 \%)$ \\
Fertilizer application & $210(100 \%)$ & $94(45 \%)$ \\
Timely weeding & $193(92 \%)$ & $132(63 \%)$ \\
Use of herbicides & $191(91 \%)$ & $21(10 \%)$ \\
\hline
\end{tabular}

especially fertilizer and herbicides (92\% of the farmers); non-availability of inputs as and when needed (90\% of the farmers); and lack of technical competence in operating essential tools, for example, spraying pumps (34.3\% of the farmers).

Relationships (effects) between type of extension method used by OGADEP extension agents and farmers' production output (maize and cassava) per hectare

Table 4 shows that more $(25.64 \%)$ farmers in the yield-category "below $1000 \mathrm{~kg} \mathrm{ha}^{-1}$ " for maize have access to only individual contact method, 20.51 per cent to mass method, while farmers in the yield-categories " $1001-1400$ and 1401-1800 kg ha $^{-1}$ " mostly have access to a combination of 'individual, mass and group methods', followed 
TABLE 4

Relationship Between Extension Methods Used by OGADEP and Farmers' Production Output (Yield) Per Hectare (Maize) $n=210$

\begin{tabular}{lcccc}
\hline Extension method & Below $1000 \mathrm{~kg} \mathrm{ha}^{-1}$ & 1001-1400 kg ha-1 & 1401-1800 kg ha-1 & Total \\
\hline Individual & $20(25.6 \%)$ & 6 & $2(6.25 \%)$ & 28 \\
Mass & $16(20.5 \%)$ & 5 & $2(6.25 \%)$ & 23 \\
Individual and mass & $11(14.1 \%)$ & 13 & $5(15.6 \%)$ & 29 \\
Mass and group & $12(15.4 \%)$ & 16 & $5(15.6 \%)$ & 33 \\
Group and individual & $13(16.7 \%)$ & 22 & $7(21.9 \%)$ & 42 \\
Individual, mass and group & $6(7.7 \%)$ & 38 & $11(34.4 \%)$ & 55 \\
\hline Total & 78 & 100 & 32 & \\
\hline
\end{tabular}

Calculated $\chi^{2}(41.65)>$ table $\chi^{2}(18.3)$ at $P<0.05 \mathrm{df}=10$

Coefficient of contingency $(\mathrm{C})=0.41$

by 'group and individual methods' and 'mass and group methods'. The result shows that farmers who are exposed to a combination of all the extension methods have greater output than farmers with access to one or two extension methods. (Note that group method was not used alone (singly) by the extension agents, but in combination with other methods).

A chi-square analysis of the data in Table 4 shows a significant relationship between farmers' access to extension methods and their level of production for maize. The degree to which this occurs is 0.41 , indicating a significant and strong relationship.

Table 5 also shows that farmers in the yield category "below $8000 \mathrm{~kg} \mathrm{ha}^{-1}$ " for cassava mostly have access to only individual method (33.4\%), followed by mass method (27.5\%). Farmers in the yield categories " $8001-10,000$ and 10,001-12,000 $\mathrm{kg} \mathrm{ha}^{-1 "}$ mostly have access to a combination of 'individual, mass and group methods,' followed by 'individual and group methods' and 'mass and group methods'. This result also shows that the output could be greater when farmers have access

TABLE 5

Relationship Between Extension Methods Used by OGADEP and Farmers' Production Output (Yield) Per Hectare (Cassava) $(n=210)$

\begin{tabular}{|c|c|c|c|c|}
\hline Extension method & Below $8000 \mathrm{~kg} \mathrm{ha-1}$ & $8001-10,000 \mathrm{~kg} \mathrm{ha}^{-1}$ & $10,001-12,000 \mathrm{~kg} \mathrm{ha}^{-1}$ & Total \\
\hline Individual & $16(33.4 \%)$ & $7 \quad(9.6 \%)$ & $5 \quad(5.8 \%)$ & 28 \\
\hline Mass & $14(27.5 \%)$ & $7 \quad(9.6 \%)$ & $2(2.3 \%)$ & 23 \\
\hline Individual and mass & $6(11.8 \%)$ & $10(13.7 \%)$ & $13(15.1 \%)$ & 29 \\
\hline Mass and group & $5 \quad(9.8 \%)$ & $12(16.4 \%)$ & $16(18.6 \%)$ & 33 \\
\hline Group and individual & $5 \quad(9.8 \%)$ & $16(21.9 \%)$ & $21(24.4 \%)$ & 42 \\
\hline Individual, mass and group & $5 \quad(9.8 \%)$ & $21(28.8 \%)$ & $29(33.7 \%)$ & 55 \\
\hline Total & 51 & 73 & 86 & 210 \\
\hline
\end{tabular}

Calculated $\chi^{2}(48.23)>$ table $\chi^{2}(18.3)$ at $P<0.05 \mathrm{df}=10$

Coefficient of contingency $\mathrm{C}=0.43$ 
to two or more extension methods. A chi-square analysis of the data in Table 5 shows a significant relationship between farmers' access to extension methods used by OGADEP and their level of production for maize. The degree to which this occurs is $0.43(43 \%)$, indicating a positive and strong association.

Tables 4 and 5 show that the type and number (combination) of extension methods farmers are exposed to greatly influence their level of output (yield). This result supports the assertion of Durant \& Ekpere (1986) that the more the farmers in sub-Saharan Africa are exposed to different and combination of extension methods, the more they learn, develop skills, and make use of new agricultural technology. This eventually leads to increase in output. Thus, considerable level of emphasis should be laid on the use of combination of extension teaching methods by extension agents.

\section{Conclusion}

The findings of this study showed that:

1. Radio is the most accessible extension medium to farmers, while their access to printed materials is very low.

2. The proportion of individual extension contact among low-adopters was found to be very low compared to that of highadopters.

3. Though farmers are highly aware of introduced technologies (recommended practices), the extent to which two of the essential components of the technology (fertilizer application and use of herbicides) were adopted is very low. This is likely to have affected the output (yield).

4. Extension methods used by OGADEP have effects on farmers' level of output in maize and cassava, especially when different extension teaching methods and media are combined.

The following are recommended:

1. An adult literacy educational programme should be organized for the farmers to increase their ability to obtain and access information from other media, especially printed materials.

2. Low-adopters should be identified and extension efforts concentrated toward them.

3. Essential inputs should be affordable and available as and when needed, while the use of organic manure (e.g. compost) as a substitute for inorganic fertilizer should be encouraged among the farmers.

4. Extension agents should be encouraged in, and regularly updated on, the use of combination of extension teaching methods and media. They should be specially trained on how to handle, select, prepare, and use them.

\section{REFERENCES}

Aboyade, O. (1997) The provision of information for rural development. Ibadan: Wemilore Press Limited. pp. 15-59.

Adams, M. E. (1992) Agricultural extension in developing countries. Longman, United Kingdom. pp. 12-21.

Adebayo, K. \& Ajayi, O. O. (2001) Factors determining the practice of crop-livestock integration in derived savanna and rainforest zones of Nigeria. ASSET Journal 1(1), 91-100.

Adedoyin, S. F. \& Adesanoye, F. A. (1996) Analysis of mass media agencies and information programming for sustainable agricultural development in Ogun State, Nigeria. In Proceedings of the 8th Annual Conference of the Nigerian Rural Sociological Association, Nigeria (ed. S. F. Adedoyin and J. O. Y. Aihonsu), pp. 61-73.

Adefuye, B. O. (1996) Innovative model for alternative utilization of agricultural extension agents for improved crop production. In Proceedings of the 8th Annual Conference of the Nigerian Rural Sociological Association, Nigeria (ed. S. F. Adedoyin and J. O. Y. Aihonsu), pp. 5058.

Adekanye, T. O. (1988) Women and rural poverty: Some considerations from Nigeria. African Notes 3, 63-67. 
Apantaku, S. O., Sodiya, C. I., Apantaku, F. S. \& Fakoya, E. O. (2000) Alternative internal sources of funds for extension services in Ogun State, Nigeria. Journal of Sustainable Agriculture 17(1), 37-54.

van den Ban, A. W. \& Hawkins, H. S. (1988) Agricultural extension and rural sociology: Introduction to tropical agriculture. Longman, London and New York. 25 pp.

Carey, A. (1999) Communication in extension: A teaching and learning guide. An FAO Publication. 16 pp.

Durant, T. J. \& Ekpere, J. A. (1986) Agricultural extension and rural development in tropical Africa. Longman, London and New York. pp. 12-23.

Ewuola, S. O. (1986) Promoting effective communication and agricultural extension strategies in Nigeria's rural development. Paper presented at the Training Course on Administration of Rural Development Programme for Officers involved in Implementation of Rural Development Programmes in Ondo State, December, 1986.

Farinde, A. J. \& Jibowo, A. A. (1996) Factors associated with effectiveness of extension teaching methods used in the transfer of agricultural innovation in Lagos State, Nigeria. Paper presented at the 8th Annual Conference of the Nigeria Rural Sociological Association (NRSA) on Sustainable Rural Development in Nigeria: An Agenda for the Third Republic, March, 1994.

FMANR (1997) Cassava development in Nigeria: A country case study towards global strategy for cassava development. Department of Agriculture, Federal Ministry of Agriculture and Natural Resources (FMNAR), Nigeria.

Huizinger, B. R., van Raalte, R. \& Rolling, N. (1982) Five approaches to rural extension. International Course on Rural Extension. International Agric. Centre, Wageningen.

Kelsey, D. \& Hearne, C. (1995) Cooperative extension work. Cornstock Publishing Associates and Cornell University. New York. pp. 3-5.

OGADEP (1995) Annual Reports. Ogun State Agricultural Development Programme, Abeokuta. OGADEP (1996) Annual Reports. Ogun State Agricultural Development Programme, Abeokuta. OGADEP (1997) Annual Reports. Ogun State Agricultural Development Programme, Abeokuta.

Tichenor, P. J. (1986) Mass media flow and differential growth in knowledge. Public Opinion Quarterly 34, 159-170. 